Francis of Assisi 
This page intentionally left blank 


\title{
Francis of Assisi
}

The Life and Afterlife of a Medieval Saint

\author{
André Vauchez \\ Translated by Michael F. Cusato
}

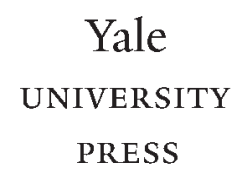

New Haven E London 
First English edition 2012. Copyright (C) 2012 by Yale University.

Originally published in French as François d'Assise: Entre histoire et mémoire. Copyright (C) 2009 by Librairie Arthème Fayard.

All rights reserved.

This book may not be reproduced, in whole or in part, including illustrations, in any form (beyond that copying permitted by Sections 107 and 108 of the U.S.

Copyright Law and except by reviewers for the public press), without written permission from the publishers.

Yale University Press books may be purchased in quantity for educational, business, or promotional use. For information, please e-mail sales.press@yale.edu (U.S. office) or sales@yaleup.co.uk (U.K. office).

Set in Electra and Trajan types by Westchester Book Group.

Printed in the United States of America.

Library of Congress Cataloging-in-Publication Data

Vauchez, André.

[François d'Assise. English]

Francis of Assisi : the life and afterlife of a medieval saint / André Vauchez ; translated by Michael F. Cusato._-1st English ed.

p. $\mathrm{cm}$.

Includes bibliographical references and index.

ISBN 978-0-300-17894-4 (cloth : alk. paper) 1. Francis, of Assisi, Saint, 1182-1226.

2. Christian saints-Italy-Assisi-Biography. I. Cusato, Michael F. II. Title.

$\mathrm{BX}_{4700 . F 6 V_{343132012}}$

$271^{\prime} \cdot 302-\mathrm{dc} 23$

[B]

2012012742

A catalogue record for this book is available from the British Library.

This paper meets the requirements of ANSI/NISO Z39.48-1992 (Permanence of Paper). 
To Denise,

without whose support this book would never have been completed; To Étienne, Anne, and Antoine, who have heard me talk about it for such a long time;

And to those friends who have patiently waited for it. 
No matter how hard we try, we always rebuild monuments in our own fashion.

But to build with only genuine stones requires a lot of work.

-Marguerite Yourcenar, Mémoires d'Hadrien 